\title{
Dialogue and Symbolism in Hemingway's the Old Man and the Sea (Dialogue) and Hills Like White Elephants (Symbolism) from Mu'tah University Students' Perspective
}

\author{
Khaled Ahmad Hmoud Al Amro \\ Sultan Zainal Abidin University- Malaysia
}

\begin{abstract}
This research paper aims at investigating the extent of Hemingway's The Old Man and the Sea of being a dialogue novel and Hemingway's Hills Like White Elephants as a novel of symbolism from Mut'ah University students' perspective. A thorough evaluation of the novels was conducted, examining dialogue in the first story and symbolism in the second story. A qualitative approach was used to collect data. Structured interviews were conducted with seven students from Mu'tah University, Faculty of Arts in Karak, Jordan. The participant students were selected randomly to be the sample for the study. The interviewees were asked about their thinking in regard to dialogue and symbolism in the study's participated novels. A questionnaire with open-ended items was utilized for this purpose. Data analysis confirmed that the Old Man and the Sea is a novel built on dialogue, and Hills Like White Elephants is a novel of symbols.
\end{abstract}

Keywords: Hemingway, Old Man and the Sea, Hills Like White Elephants, Dialogue, Symbolism

DOI: $10.7176 / \mathrm{JLLL} / 60-05$

Publication date:September $30^{\text {th }} 2019$

\section{Introduction}

This research paper aims at examining two of Hemingway's novels in terms of dialogue in the Old Man and the Sea and Symbolism in Hills Like White Elephants according to a sample of Mu'tah University students' perspective.

In regard to the first novel which is undoubtedly Hemingway's masterpiece, is a simple story about a fisherman Santiago and his battle with a great fish. It is about Santiago (the old man) and Manolin (the boy) speak in a conversational style, simply and efficiently, saying what is on their minds without complications. Their dialogue which consists of simple words is meant to reveal the period and location of the story, which is set in Cuba while using English, Spanish, and Cuban idioms which indicates to a realistic setting.

As it is mentioned earlier that ialogue throughout the novel takes place between the old man and the boy, or the old man with himself, or directing his speech to the fish, sea, boat and God." "You think too much, old man", he said aloud to himself," I wish I could show him what sort of man I am. But then he [the fish] would see the cramped hand. Let him think I'm more man than I'm and I will be so"

Dialogue reflects Santiago 's slogan; he fits the quality very likely, although he has not caught any fish for a long time, he does not give up. "Fish... I will stay with you until I am dead" (Hemingway 43).

Talking to himself reveals many themes such as manliness and accepting challenge The Marlin fish was too big it could easily break skiff, and swim away, but The Old Man neglects this crucial fact. He insists on winning the battle and the fish. He has fought many times before unlike this one "I have never seen or heard of such a fish" (Hemingway 63)

Again, one sees the old man talks to himself" If he will jump, I can kill him. But he stays down for ever. Then I will stay down with him forever" (Hemingway 50). This type of dialogue reflects Santiago's triumph and dignity "I must think of nothing and wait for the next ones" (Hemingway 96)

Amazingly, Hemingway uses dialogue in very simple words that reflect the deepest thoughts in the old man's mind," I am too old to club sharks to death. But I will try as long as I have the oars and the short club and the tiller" (Hemingway 96-7). "I told the boy I was a strange man", he said. "Now is when I must prove it"

This and more are explained with more details in this study.

In regard to symbolism in the second novel Hills like White Elephants

Again, Hemingway never used complicated words. Not even for the words which could replace approximate and multiple words clauses or phrases. Yet, every meaning he needed clarified, he did. (Forseka 2008)

Ernest Hemingway (1899-1961) wrote "Hills like White Elephants" in 1927. The short story showcases most of his originality as a writer in the use of imagery, symbolism, irony, rhythmic language, dialogue, implicature, etc.

Hemingway's style of discussing social issues, by fragmentarily presenting how the story continues step by step, symbolically revealing the psychological workings of the two characters, the symbolic exposition of every element connected with the issue of pregnancy which is the focal problem in the story. That is meant to 
familiarize the reader with Hemingway's style where imagery and symbolism are the means of narration that help to generate a paradox as the overarching aesthetic achievement in the story as well as symbolism of transition (Foseka 2008)

Moreover, reviewed the story shows that Hemingway's use of imagery in generating implicatures rather than carrying out explicit narrative descriptions. (Bowen 1945) One can notice that throughout the story for example, the "long and white" hills across the Spanish landscape featured by the river Ebro dominate the drop scene. When the conversation between the two protagonists starts, they tend to inspire the imagination of the girl. She compares them to white elephants which do not exist on earth or are not real. "A white elephant" is a cliché in English to describe "an expensive and often rare or valuable possession whose upkeep is a considerable financial burden" or "something with a questionable or at least very limited value". (Bowen 1945) Thus, the physical look of the hills in the hot sun has a logical relationship with the girl's comment on them. But they mainly help to elicit the American's nonchalant attitude to her pregnancy. The man considers the unborn baby is a "white elephant" as he believes that dissuasion resulting in determination: Paradox in "Hills Like White Elephants" by Ernest Hemingway it has no crucial role to play in sustaining their relationship and that it would only absorb their energy for its growth and become a burden on them for the rest of their lives. The thermal imagery of the sunny atmosphere is supported by the monotonous location of the station between the two lines of rail shining in the blazing sun, in the absence of any shade or trees around. The two railway lines continue to the end parallel to each other but without getting connected at all, symbolizing the disharmony that prevails right now in the relationship between the two. The restaurant in the vicinity of the station is the location where the two waits for the train. Hemingway extends the thermal metaphor even further by describing the shadow of the building as warm. The bamboo-bead curtain that hangs across the open door into the bar suggests Spanish art or handicraft, adding an element of Spanish ness to the atmosphere. It seems this isolated remote railway station has its own problems of health. The function of the bamboo-bead curtain is "to keep out flies". (Ralph 1964) Hemingway sees reality as a reality. Flies, attracted to garbage, are suggestive of the contaminated surroundings. Images of dullness, discomfort, ugliness, insecurity, dirt, and sterility help to foreground the conflict between the American and the girl who are in a mood of transition. (Ralph 1964) The dominant appearance of the hills influences the function of all signifiers in the story.

Furthermore, frozen feelings in hot weather, the American and the girl appear at the restaurant to drink something. It is the girl who raises the question about drinks. "What should we drink?" Her forwardness and initiative in all things they do is clear in her adaptation to the restaurant atmosphere by removing her hat and placing it on a table. The man seems only to follow her commands and suggestions. Throughout the ordering of drinks, the man just makes one passing comment on the atmosphere. "It's pretty hot." Other than that, he only communicates with the restaurant woman, in order to accommodate the girl's desire to drink a large mug of beer. The restaurant woman operates just at the commands given to her. No feelings are being exchanged between them. The man and the girl look frozen in their minds although the weather is hot.

Hallucinations of White Elephants as Hemingway portrays the atmosphere, thirst, heat and fatigue together cause the girl to develop hallucinations out of the entities present in the surroundings. The "line of hills" in the "brown and dry" landscape looks "white in the sun". The girl's exclamation "They look like white elephants," is basically influenced by the oppressive physical setting and the weary psychological condition she has developed during the journey (Philip Young 1972)

Thus, one can see that symbolism of transition when Hemingway provides a symbolic background for the short story, in order to foreground the conflicting state, in which the two characters, the American and the girl, interact with each other. The symbolism of transition formed by the two rails supported by images of dullness, discomfort, ugliness, insecurity, dirt, and sterility merge with the psychological paralysis of the characters depicted through their frozen behavior that contrasts with the scorching heat. Dr William Tarvin (2014) claims "elephants would probably be a symbol of fecundity"; and as the phrase "white elephants" in English means idiomatically "a property requiring much care and expense and yielding little profit" or "an object no longer of value to its owner but of value to others". (Tarvin 2014)

Finally, this research paper examines dialogue in Hemingway's Old Man and the Sea and symbolism in Hills like White Elephants from a sample of Mu'tah University students' perspective.

\section{Literature Review}

Santiago, Hemingway's hero of The Old Man and the Sea, is not everyman, yet he does represent man in his most elemental greatness (Philip Young 1972).

Santiago is a man with uncomplicated thoughts, a simple life, and simple, life-giving wants. He has love and his work-fishing. After the debacle with the sharks is over, Santiago "sailed lightly now and he had no thoughts nor any feelings of any kind". He loves the boy Manolin and the boy loves him. The boy's love is a powerful influence on his life. "The boy keeps me alive, he thought". Thus, and the novel tells us, Santiago's life has essence the love between him and the boy, and his love for the nobility of nature's creatures. He respects the 
process of life, and not necessarily the product. He is satisfied that he caught the big fish well, and that it was a good death. Most of the novel's events are expressed through dialogue. Having lost the fish to sharks, he simply does what is necessary to return home. The fish is no longer part of his journey. He let the fish go, figuratively, when he said, "I wish it were a dream and that I had never hooked him. I'm sorry about it, fish. It makes everything wrong".

Talking to himself, the old man says "Perhaps he is too wise to jump. He could ruin me by jumping or by a wild rush". Santiago thinks about and talks to the great fish as it pulls the skiff out to sea. The fish is his brother and his friend. One can observe that Santiago, the fisherman, is an everyman character, he is an individual, yet he represents the struggles of all men as they go through life and his bad luck represents the vagaries of life that afflict all people. (Leon Edel. 1984)

The following is the previous research that deals especially with The Old Man and The Sea (1952) novella.

The first research was conducted by Bahram Paul (StudyMode, 2006) entitled Old Man and the Sea: Parable of Man's Struggle with Natural Force. The result of research shows that a man may grow old and be wholly down on his luck, but he can still dare, persist when he is defeated or thwarted, and thus by manner of his losing can win a victory. And the rules' must not be lost sight of- the procedure, the technique, the craft, the skill. And this is applicable to life as a whole, to man's earthly existence, to the heavy odds which man has to face and which he must not shrink from even in the sure knowledge of losing the fight. (Paul2006)

The second research was conducted by Venansius Pandiangan (USU, 2008) entitled Human Existence As Reflected in Ernest Hemingway's The Old Man and The Sea. The result shows that human existence is presented through the character Santiago, an old sailor, in the novel The Old Man and the Sea, Santiago is a representation of an individual with characteristics that portray existence as a human being. These characteristics include subjectivity, conscious being in the world, contingency, anti-materialism, humanity and faith. These things are characteristic features of human existence and Santiago as the main character in the novel have these characteristics. More away, the fulfillment of the individual character characteristics through Santiago is a representation of human existence as a whole.

The third research was conducted by Sophie Chen (National Dali Senior High School, 2007) entitled A Man Can Be Destroyed But Not Defeated The Struggle of Life in "The Old Man and the Sea." The result shows that on the eighty-fifth day Santiago goes very far out to sea and hooks a marlin. Santiago endures a great struggle with an uncommonly large and noble marlin only to lose the fish to rapacious sharks on his way back to land. Despite this loss, Santiago ends the novella with his spirit undefeated. He represents the courage, strength and endurance of the human race. He struggled between love and hate like all men do. However, the thing that truly defeated Santiago was his pride.

In regard to Hemingway's Hills Like White Elephant, there are an ample of studies discussing every aspect of the novel such as:

Fifit Rizkiyani, Faza Lutfiyana Sept 2017, In Ernest's story, "Hills like White Elephant", Ernest tries affect the reader in several ways. This story uses in the morning when the sun rises as the time setting proves with the sentence "Close against the side of the station there was the warm shadow of the building and a curtain, made of strings of bamboo beads, hung across the open door into the bar, to keep out flies. The American and the girl with him sat at a table in the shade, outside the building". For the setting of place, the author uses at the train station in Spain. Proves with the sentence "On this side there was no shade and no trees and the station was between two lines of rails in the sun. Close against the side of the station there was the warm shadow of the building and a curtain, made of strings of bamboo beads, hung across the open door into the bar, to keep out flies". Especially, at the outside of bar where the man and the girl are drinking beers while waiting the Express train from Barcelona. The tone and atmosphere in the story of "Hills like White Elephant" is full of crisis. Why? Because as long as the story happened is full of the sarcastically conversation between the American man and the girl. The topic they are talking about is the operation. The tone and atmosphere of each character are that as same in the uncontrolled emotion because among of them happened different idea and arguments.

It looks in the way they speak. The conflict happened in the story is that about the American man wants the girl has the operation. He says that the operation is the best way for them to have a whole life, better life in the future without having a burden, and they can go everywhere they want. However, the girl disagrees with his desire. And because she was stressed to have an annoying speaking of the American man, she tries to shout loudly to make the American man stops talking. The resolution of the conflict is the American man start getting hopeless. He says to the girl no to do the operation if she doesn't want to do it. Then he takes the heavy bags. There are three main symbols in the story. They are the hills, white elephants, and the railroad station. And they represent an abstract idea of moral qualities.

The author used those symbols because they can develop the theme of the story. In the beginning of the story, the girl similes herself with the hills, and she says that the hills like white elephant. Her talking has a meaning. That is she thinks that she herself doesn't have a precious thing anymore in her life. Those are the symbols of thing which isn't precious anymore. The symbol which can be found in the story "Hills like white 
elephant" is white elephant like in some part of the story that can be proved in the sentence "They look like white elephants," she said". Historically white elephant is a gift that has no usefulness to the recipient, especially when any utility in the item is overshadowed by the cost of its upkeep. So, in the story "Hills like White elephant" the hidden meaning is that 'The American,' presumably the girl's husband or lover, sees the pregnancy as a white elephant gift, as we can tell from his frequent and falsely supportive nudges to get her to have the procedure, or abortion.

The second symbol is the elephant in the room. The English expression 'avoiding the elephant in the room' colorfully indicates a situation in which someone refuses to address a typically weighty, important, or just obvious topic. For the girl, her pregnancy is not a gift that she's unwilling to receive. However, when it comes to talking about the situation with the American, she'd rather avoid the discussion altogether, even begging at one point 'Would you please stop talking?' The next symbol is the railway station. The lonely rail station that serves as the backdrop for Hemingway's story represents an important decision to be made - much like a crossroads in other stories. Its isolation also reflects the girl's own desperate loneliness she feels in facing this situation, despite the American's constant interference. The last symbol we will talk about is the landscape. Landscapes, especially rugged ones, were a favorite thematic element for Hemingway and no less so in 'Hills like White Elephants.

From the symbols which were portrayed in the story, it shows how the man and the girl expressed their love. The man seems don't want to have the child because he wants the girl to do the operation. Everything in the story indicates that the man definitely wants the girl to have an abortion. Even when the man maintains that he wants the girl to have an abortion only if she wants to have one, we question his sincerity and his honesty. When he says, "If you don't want to you don't have to.

I wouldn't have you do it if you didn't want to," he is not convincing. From his earlier statements, it is obvious that he does not want the responsibility that a child would entail; seemingly, he strongly wants her to have this abortion and definitely seems to be very unresponsive to the girl's feelings. But on the conversation in the story the girl seems do not want to do the operation, she just gives the answer unclearly to the man whether she wants to do the operation or not. We feel that the girl is not at all sure that she wants an abortion. She's ambivalent about the choice. We sense that she is tired of traveling, of letting the man make all the decisions, of allowing the man to talk incessantly until he convinces her that his way is the right way.

He has become her guide and her guardian. He translates for her, even now: From the depth analysis of the story, from its symbol and figurative language which are used in the story, it certainly shows the darkness of love which is caused by forbidden love of the girl and the man, the man strongly shows his irresponsible of the pregnancy of the girl because he want the girl to do the operation, and he said that the operation is "simple". But on the other hand, the girl seems uncertain about the abortion. From all the conversation we can know that between the man and the girl have different perception about the operation of the pregnancy of the girl, and they also seem have different perception about their feeling of love. So, it looks like something hidden in their love which caused their darkness of love. Hemingway presents the themes of the story via the utility of symbols, as we see in this research paper.

\section{Methodology}

Since the study is about the analysis of human behavior, qualitative method is used in this study. The technique of analyzing data was divided in two steps. The first step was identifying the literary elements of the data by selecting and focusing on the important features linked with the study. The second step was analyzing the data and making conclusion. The analysis was presented descriptively

Literary elements consist of the two participated novels as primary data source, relevant previous literature specialized journals, internet as secondary data source, with the focus on dialogue in the Old Man and the Sea and symbolism in Hills like White Elephants.

In order to achieve the study's objectives seven students from the Mu'tah University were chosen randomly so as to express their opinion in regard to the dialogue and symbolism in the participated novels.

\section{Procedures}

A permit was obtained from the university president to allow us conducting interviews with students.

There are many reasons to use interviews for collecting data and using it as a research instrument. They are mainly useful in cases where there is need to attain highly personalized data, as well as in cases where there are opportunities for probing to get underlying factors. They also become a viable option where there are limited respondents and a good return rate is important, and also where respondents are not fluent in the native language of a country, or where they have difficulties with written language (Gray: 2004).

Prior to the interviews a meeting was held with participants in which they became aware of the purpose and the objectives of the study, and their crucial role in its success.

The note-taking of collecting data is the library research, it can be obtained by:

- Reading some related books and articles related to the object of study 
- Accessing internet to get several information

-. Taking note important parts in both the primary data and secondary data

-. Arranging the data into several categories

Technique of the Data Analysis In analyzing the data, the researcher employs descriptive qualitative method: in which the data will be collected, described and analyzed.

A short list of open-ended questions is prepared so as to be answered by them, as follow:

*From the frequent dialogues what is the message of the Old Man and the Sea?

*What are the major themes in the Old Man and the Sea?

* How does the title Hills Like White Elephants relate to the story?

* What do the Hills Like White Elephants symbolizes?

* What are the main symbols in the story Hills Like White Elephants?

\section{Results}

Data collected from interviewees is quantitively analyzed, results revealed the following:

Hemingway uses dialogue as an effective device to make his novels be more attractive, for example from The Old Man and the Sea: "What do you have to eat?" the boy asked. "No, I will eat at home; do you want me to make the fire?" "No, I will make it later on, or I may eat the rice cold."

Here we can see the words are very colloquial. Thus, the speech comes to the reader as if he were listening. Hemingway has captured the immediacy of dialogue skillfully and has made the economical speech connotative heroic actions of the Old Man and an end to which he is destined -Free Will and Fate in The Old Man and The Sea

A man can never act in a cowardly way., yet a stoic man like Santiago with the everlasting pain endurance cries out: - A man can be destroyed, but not defeated. Free Will "I wish I was the fish, he thought, with everything he has against only my will and my intelligence" (Hemingway 54)

But I will show him [the fish] what a man can do and what a man endures.

I couldn't fail myself and die on a fish like this

Furthermore, the old man is often found talking to himself, often aloud, because he's alone in the sea Hemingway used dialogue or talking to himself in building metaphors

(After a fish was dead): The Fish's eye looked as detached as the mirrors in a periscope or as a saint in a procession.

The sail was patched with flour sacks and, furled, it looked like the flag of permanent defeat.

The walls were painted bright blue and were of wood and the lamps threw their shadows against them. The negro's shadow was huge and it moved on the wall as the breeze moved the lamps.

Just before it was dark, as they passed a great island of Sargasso weed that heaved and swung in the light sea as though the ocean were making love with something under a yellow blanket.

Participant expressed that dialogue has led to several themes which can be considered as the novel's themes such as :

\section{Courage}

The dialogic approach indeed makes his fictions more delicious. The characters of his novels give the impression that they are engaged in live-talks as they exchange dialogue among themselves. The expression of uncontrollable emotion in a forbidden and composed variety perhaps exhibits the uniqueness of his writings.

It is an old man catching a fish, yes; but it is also a great artist in the act of actually writing about the struggle. Nothing is more important than his craft, and it is beloved, but because it may be struggled with and mastered, it is also a foe, enemy to all self-indulgence, to all looseness of feeling, all laxness of style, all soft pomposities. (Carlos P.134)

old man's struggles on it form a brief episode.

the old man, the sea, and the denizens of the sea as characters, for the most part, and the narrative focus is almost continually on the old man except for one or two minor shifts as in the description of the Mako shark.

Hemingway uses dialogue as an effective device. Here is an example chosen from The Old Man and the Sea: "What do you have to eat?" the boy asked. "No, I will eat at home; do you want me to make the fire?" "No, I will make it later on, or I may eat the rice cold." Here we can see that such interpolations as "he said" have frequently been omitted and the words are very colloquial. Hemingway has captured the immediacy of dialogue skillfully and has made the economical speech connotative. But it is good to note that Hemingway's style is deliberate and artificial, and is never as natural as it seems to be.( English language teaching vol. 1, No.2 December 2008)

But most of the boats were silent except for the dip of the oars" (Hemingway 21-2). The fishermen go to areas they know to be safe and always are cautious not to damage the life that they have created for themselves. - People without target are just like boats without oars; they move according to the current of the sea. The quotation fits Santiago strongly; he attempts to return his dignity by catching a fish even if he risks his 
life. "Where are you going? The boy said. Far out..." (Hemingway 9) "The Old Man knew he was going far out..." (Hemingway 22) “... are you strong enough now for a truly big fish? I think so...” (Hemingway 9) "There is no such a fish if you are still strong" (Hemingway 17) Persistence (Patience) For certain tasks of great length, persistence is needed even more than energy. The kind of persistence is that exercised in spite of repeated failures. Persistence and patience are Santiago 's slogan; he fits the quality very likely, although he has not caught any fish for a long time, he does not give up. - Fish... I will stay with you until I am dead. II Hemingway 43). The Marlin fish was two feet greater than the skiff, it could easily break it and swim away, but The Old Man neglects this crucial fact. He insists on winning the battle and the fish. He has fought many times before unlike this one - I have never seen or heard of such a fishl (Hemingway 63), he knows what he ought to carry out despite its peril. - If he 22 will jump I can kill him. But he stays down for ever. Then I will stay down with him forever" (Hemingway 50).

"I wish I had the boy"

"Fish, I love you and respect you very much. But I will kill you dead before this end"

\section{Manhood and Masculinity}

Exploring the themes in The Old Man and the Sea shows Hemingway's philosophy of life as exemplified by manhood, and Santiago's (and the marlin's) willingness to struggle against an undefeatable opponent.

Santiago proves his manhood by refusing to be defeated, notwithstanding the incredible odds against him. From the beginning of the novel, we learn of Santiago's hopeless struggle:

1. He has gone fishless for 84 days, something, which if you're a fisherman, is detrimental to your existence.

2. Manhood in The Old Man and the Sea, as demonstrated by Santiago, is done in isolation, far out beyond other fishermen, where the big fish dwell.

3. Even after Santiago catches the marlin, the struggle remains hopeless as sharks attack his catch. Santiago still fights. Injured and beaten, but never defeated, Santiago reaches deep to resist inevitable defeat.

Pride

Another theme is Santiago's pride and its influence on his behavior. Hemingway, however, does not condemn Santiago, for it is Santiago's pride that motivates him to:

Keep fishing after 84 fishless days

Keep fighting the marlin despite intense suffering

Keep fighting the sharks without hope of victory

It is these three things that make Santiago a man, according to Hemingway, regardless of the end result.

Symbolism in The Old Man and The Sea Participant students expressed the following: Ernest Hemingway is famous for his mastery of utilizing images and symbols in almost all of his works: Symbolism in The Old Man and The Sea Hemingway seldom employs adjectives and abstract nouns. The simplicity of the sentences used by Hemingway in this masterpiece can be seen clearly in this example: "No, I will eat at home; do you want me to make the fire?" "No, I will make it later on, or I may eat the rice cold." (p.25) Here the reader can see the use of direct style, simple words yet colloquial and short sentences as well. Hemingway connects the different parts of the sentences in a direct and successive way, generally linked by the conjunction « and ». Since Hemingway's task is creating real people, he often utilizes dialogue as an effective gadget. dangerous strengths in life that fill no need. Sadly, the sharks, that symbolize evil and abhorrence, destroy the meat of the great fish.

Participants continued expressing their point of view in regard to the second novel as follow:

\section{Stylistic Analysis of Hills Like White Elephants}

In "Hill Like White Elephants," Hemingway narrates a story of a man and woman who are drinking beer and anise liqueur while they are waiting for a train at a station.

Through the text, seven occurrences of the word "know" designate what the American knows. For examples, the man says "I know you wouldn't mind it" and "I know we will" (Hemingway, 1927). In other instances, he uses the word know to tell her what she knows. For examples, he says, "You know how I get when I worry" and "You know I love you." There is also another instance where he uses "know" to explain her girlfriend's lack of knowledge about whether to mix the Anis del Toro drink with water or not. The progress of the narrative clearly shows that there is a prominence of "know" and "want" in the initial sections that transforms to "feel" and "realize" in the closing sections

The language used affirms that the issue being discussed is very sensitive and personal. "It," as used in the narrative, refers to an ambiguous subject that is the main issue of concern between the two individuals Symbols in "Hills Like White Elephants"

In "Hills like White Elephants" Ernest Hemingway doesnt give us the straightforward information. Rather, he gives us some info by using symbols,

The scenery plays a major role in the story. Hills which are like white elephants represent a belly of a pregnant 
woman.

Hemingway describes the setting "On this side there was no shade and no trees and the station was between two lines of rails in the sun... the country was brown and dry. Later, the other side of the train station is described when "the girl stood up and walked to the end of the station. Across, on the other side, were fields of grain and trees along the banks of the Ebro. Far away, beyond the river, were mountains. The shadow of a cloud moved across the field of grain and she saw the river through the trees."

In the description of the first side of the train tracks, the atmosphere is dry and unpromising. It describes the state of the couple's relationship if their unplanned pregnancy results in death. Things can't go back to the way they were, their lives will always be impacted by the decision to carry out the abortion.

On the other hand, the other side of the tracks seems plentiful and alive. The fields of grain could depict fertility, just as the Ebro river symbolizes life. Jig is allowing her mind to wander to what it would be like to be a mother and have this child.

The shadow that creeps over the peaceful scene could represent two things.

American boyfriend who is continually intrusive with his opposing opinion on the subject of abortion

How society would frown upon a woman who is pregnant and not married.

The coming of the train is also symbolic. Traditionally, a train goes one way. Once it comes, it goes. Symbolically, the train represents girls choice. Like the coming of the train, if she decides to abort the baby, there is no turning back.

As the man takes both of their bags over to the tracks, he is hoping that Jig will go through with the surgery. He is still uncertain as to whether she will in fact go through with the abortion, but lets his opinion be known by taking their luggage and setting it by the tracks to be loaded on the upcoming train.

The drinks that the American and the girl share are another instance of symbolism regarding Jig's decision about the abortion, since it is widely known that alcoholic beverages affect fetus.

There is a recurring theme of the number "two." For instance, the train stopped for "two" minutes, the couple drinks "dos" cervezas, they receive "two" glasses of beer, "two" felt pads and the American carries their "two" heavy bags to the other side of the train tracks. It could inspire two different reading

The first could be that the relationship between the couple is the largest the relationship can span; they can't include a third person into their relationship.

The other way to read this is that perhaps "two" refers to Jig and her baby. Jig is still weighing the possibility of becoming a mother because she has not yet made a decision as to whether she will abort the baby or not.

The term "white elephants" originally was used in Indian cultures where a white elephant is "a possession unwanted by the owner but difficult to dispose of". The term originally came about in an apocryphal tale about the King of Siam who would "award a disagreeable courtier a white elephant, the upkeep of which would ruin the courtier". In sum, a white elephant is an unwanted gift; much like Jig's pregnancy seems, especially to the American like an unwanted thing.

Moreover, the symbolism of the white elephants further emphasizes the subject of the story.

When the girl comments that the hills look like white elephants and the man says he's never seen one, she answers, "No, you wouldn't have." If the hills represent female fertility, swollen abdomen, and breasts, she could be suggesting that he is not the type of person ever to intentionally have a child.

But if we consider a "white elephant" as an unwanted item, she could also be pointing out that he never accepts burdens he doesn't want. Notice the symbolism later in the story when he carries their bags -- covered with labels "from all the hotels where they had spent nights" -- to the other side of the tracks and deposits them there while he goes back into the bar, alone, to have another drink.

A New Dialogue for A New Genre: Hemingway's Legacy Hemingway systematized a treatment of dialogue in a manner now scarcely possible to appreciate, so much has the Hemingway usage taken the place of what went before. - Anthony Powell (110) What exactly was it that "went before" Hemingway's revolutionary innovations in fictional dialogue? For Henry James, whose theory and practice of dialogue were exemplary in the late nineteenth century, fictional dialogue was purely complementary; its proper and only function was to be "directly illustrative of something given us by another method" of presentation ("London" 1404). The idea that dialogue could crystallize situation or advance plot was, to James, ludicrous, and any attempt to have dialogue undertake such a "constructive office" he termed "suicidal" ("Balzac" 137, "London" 1404). In fact, even the notion of "really constructive dialogue, dialogue organic and dramatic, speaking for itself, representing and embodying substance and form" was an "abhorrent thing," appropriate to the theater but never to fiction ("Preface" 1127, "Balzac" 137). Moreover, James, for whom mimesis was a paramount goal of fiction, did not believe that direct speech was capable of being mimetically reproduced, and so he called for writers to recognize "the impossibility of making people both talk 'all the time' and talk with the needful differences" ("London" 1404"). Hemingway, of course, owed a great deal to James, whose own dialogue served as a powerful model for the young author in its indirection, ambiguity, and portrayal of communication as veiled, partial, and difficult.7 But James's theories of fiction-despite his movement toward increased dramatization, foreshortening, and the 
effacement of the narrator-derived from his work in the nineteenth-century novel of manners. The sine qua non of that genre was the dense depiction of social texture and the representation of lapse of time, and dialogue for purposes other than illustration interfered with these fictional aims ("Howells" 505-06). Hemingway's prosaics, however, derived from an entirely different genre-the emerging modern short story-and they were influenced as well by his experiences in journalism, by the impressionism of Stephen Crane, Stein's theories of repetition, Joyce's complex dialogue patterns, and the imagism of Ezra Pound. The modern short story's demands for radical compression, which led to the need for a high degree of suggestiveness and implication, eliminated the portrayal of social texture and duration that lay at the heart of the novel of manners. These generic demands enabled Hemingway, perhaps even compelled him, to rely on and further compress dialogue, allowing it to assume a greater responsibility in fictional composition than ever before, even to the point of removing almost completely the minimal narrative commentary without which, James had felt, fiction would cease to be fiction and would cross over into drama.

\section{Conclusion}

This research paper through the use of Mutah University students as a sample explored two of Hemingway's novels, The Old Man and the Sea in terms of being a dialogue novel and Hills like White Elephants in terms of being a novel of symbolism.

Participants read the two novels very closely and answered the questions that submitted to them through a structured interview

They concluded that the Old Man and the Sea is a dialogue novel while the other novel Hills Like White Elephants is a novel of symbolism.

\section{References}

- $\quad$ "William Dean Howells" [1886]. In Henry James: Literary Criticism: Essays on Literature, American Writers, English Writers, The Preface to the New York Edition.

- $\quad$ Bowen, Elizabeth. "Notes on Writing a Novel" [1945]. In Collected Impressions. New York: Knopf, 1950. 249-63.

- Ciardi, John. "The Language of an Age." Saturday Review 44 (29 July 1961): 32. Dodd, Lee Wilson. "Simple Annals of the Callous." Book review of Men Without Women, by Ernest Hemingway. Saturday Review of Literature 4 (19 Nov. 1927): 322-23.

- Ernest Hemingway, The Old Man and the Sea

- Ed. Jackson J. Benson. Durham: Duke UP, 1990. 288-99. Stein, Gertrude. "Composition as Explanation" [1926].

- $\quad$ Ed. Leon Edel. New York: Library of America, 1984. 1120-37.

- $\quad$ Ed. Leon Edel. New York: Library of America, 1984. 1387-1413. [1908].

- $\quad$ Ed. Leon Edel. New York: Library of America, 1984. 497-506.

- $\quad$ Ed. Philip Young. New York: Scribner's, 1972. 13-15.

- $\quad$ Ehrenburg, Ilya. "The World Weighs a Writer's Influence: USSR." Saturday Review 44 (29 July 1961): 20.

- $\quad$ Ellison, Ralph. "A Rejoinder" [1964]. In "The World and the Jug." In Shadow and Act. New York: Vintage, 1972. 107-43.

- $\quad$ Ford, Ford Madox. Joseph Conrad:A Personal Remembrance. Boston: Little, 1924. Hemingway, Ernest. "An Alpine Idyll." In Men Without Women. [1927].

- Goodman, S., \& O'Halloran, K. (2006). The art of English: literary creativity. Palgrave Macmillan.

- Hemingway, E. (1927). Hills Like White Elephants.

- In Henry James: Literary Criticism: French Writers, Other European Writers, The Prefaces to the New York Edition.

- In Selected Writings of Gertrude Stein. Ed. Carl Van Vechten. New York: Vintage, 1972. 513-23. Welty, Eudora. "Looking at Short Stories" [1949].

- $\quad$ In The Eye of the Story: Selected Essays and Reviews. New York: Vintage, 1979. 85-106. Wharton, Edith. The Writing of Fiction. 1925.

- INTERNATIONAL JOURNAL OF SCIENTIFIC \& TECHNOLOGY RESEARCH VOLUME 4, ISSUE 12 , DECEMBER 2015 ISSN 2277-8616 125 IJSTR@2015 www.ijstr.org Symbolism In Ernest Hemingway’s The Old Man And The Sea Sandamali K. P. S

- $\quad$ Isenberg, Arnold. "The Technical Factor in Art." Journal of Philosophy 43.1 (1946): 5-19. Rpt. in Aesthetics and the Theory of Criticism: Selected Essays of Arnold Isenberg. Eds. William Callaghan et al. Chicago: U of Chicago P, 1973. 53-69.

- $\quad$ James, Henry. "The Lesson of Balzac" [1905]. In Henry James: Literary Criticism: French Writers, Other European Writers, The Prefaces to the New York Edition. Ed. Leon Edel. 
- $\quad$ Letter to Hadley Mowrer. 25 Nov. 1943. In Ernest Hemingway: Selected Letters 1917-1961. Ed. Carlos Baker.

- $\quad$ Levi, Carlo. "The World Weighs a Writer's Influence: Italy." Saturday Review 44 (29 July 1961)

- $\quad$ Lewis, Wyndham. "Ernest Hemingway: The 'Dumb Ox."' In Men Without Art. London: Cassell, 1934. $17-$ 40.

- $\quad$ Link, A. (2004). Staking Everything on It: A stylistic analysis of linguistic patterns in "Hills Like White Elephants." The Hemingway Review, 23(2), 66-74.

- $\quad$ Macauley, Robie, and George Lanning. Technique in Fiction. 2nd ed. New York: St. Martin's, 1987.

- Madariaga, Salvador de. "The World Weighs a Writer's Influence: Spain." Saturday Review 44 (29 July 1961):

- Marquez, Gabriel Garcia. "Gabriel Garcia Marquez Meets Ernest Hemingway." New York Times Book Review (26 July 1981):

- Morrison, Toni. Playing in the Dark: Whiteness and the Literary Imagination. Cambridge: Harvard UP, 1992. Parker, Dorothy. "A Book of Great Short Stories." 21.

- $\quad$ New York: Library of America, 1984. 115-39 "London Notes" [1897]. In Henry James: Literary Criticism: Essays on Literature, American Writers, English Writers, the Preface to the New York Edition.

- New York: Octagon, 1966. Woolf, Virginia. "An Essay in Criticism." Book review of Men Without Women, by Ernest Hemingway. New York Herald Tribune Books 9 (9 Oct. 1927): 1, 8

- $\quad$ New York: Scribner's "Indian Camp." In In Our Time. [1925].

- $\quad$ New York: Scribner's, 1970. 15-19. .."Three Shots." In The Nick Adams Stories.

- $\quad$ New York: Scribner's, 1970. A Canary for One." In Men Without Women. 103-108.

- $\quad$ New York: Scribner's, 1981. 554-56Hills Like White Elephants." In Men Without Women. 39-44.

- Reynolds, Michael. Hemingway: The Paris Years. Oxford: Basil Blackwell, 1989. The Young Hemingway. Oxford: Basil Blackwell, 1986.

- $\quad$ Savage, D. S. "Ernest Hemingway." In Focus Two. Eds. B. Rajan and Andrew Pearse. London: Dobson, 1946. 7-27.

- Smiley, Pamela. "Gender-Linked Miscommunication in 'Hills Like White Elephants."' The Hemingway Review 8.1 (1988): 2-12. Rpt. in New Critical Approaches to the Short Stories of Ernest Hemingway. 